Editorial

\title{
The International Archives of Otorhinolaryngology will turn 25 years in 2021 !
}

\author{
Ricardo Ferreira Bento*1] \\ ${ }^{1}$ Department of Otorhinolaryngology, Faculdade de Medicina da \\ Universidade de São Paulo (FMUSP), São Paulo, Brazil,
}

Int Arch Otorhinolaryngol 2021;25(1):e1-e3.

In 2021, the International Archives of Otorhinolaryngology (IAO) will complete 25 years of uninterrupted publication of clinical, basic research and systematic review articles, contributing effectively to the progress of scientific knowledge in Otorhinolaryngology, Audiology, Speech Therapy and related sciences.

The scientific journal is a publication sponsored by the Otorhinolaryngologic Foundation and edited by Thieme Medical Publishers. This year's is the 25th volume published since $1997,{ }^{1,2}$ and it is composed of original articles and literature reviews carefully selected by a large international editorial board and peer-revied by renowned researchers who voluntarily contributed to add greater quality to the content of the articles evaluated.

With the COVID-19 pandemic crisis, the year 2020 represented a challenge to maintain the journal regarding the serious social and economic problems faced worldwide, but the editorial team did not lack the will and determination to keep the journal going.

The IAO was the first electronic journal in the world, so much so that its first name was International @rchives of Otorhinolaryngology, with the "@” referring to the concept of open access, and it used the newly-created internet for the universal and free dissemination of its files. ${ }^{2-4}$

Although the internet already existed for communication between academic centers since 1983, it started to be used by the general population around 1993-1994, initially with dial-in networks and few resources. ${ }^{5}$

In this context, Ricardo Bento, professor of Ear, Nose and Throat (ENT) at The School of Medicine of University of Sao Paulo (Faculdade de Medicina da Universidade de São Paulo, FMUSP, in Portuguese) and Claudio Lazzarini, otorhinolaryngologist at the Otorhinolaryngology Service of FMUSP, who

1st. Editor of the International Archives of Otorhinolaryngology.

Address for correspondence

Ricardo Ferreira Bento, MD, PhD,

Departmento de

Otorrinolaringologia, Faculdade

de Medicina da Universidade de

São Paulo, Av. Dr. Enéas de

Carvalho Aguiar, 255, $6^{\circ}$ Andar,

Sala 6.167, São Paulo, 05403-000,

Brazil

(e-mail: rbento@gmail.com). were enthusiastic about this new technology, which was even contested by many who did not believe in its future, decided to create a scientific journal with printed and electronic versions, with a website and open-access articles. It was the first in the world. ${ }^{2,4}$ The journal was the first medical journal to publish pictures in anaglyph 3D coming with the special glasses in 2000 (issue 4, volume 2). The journal official scientific publication of the Otorhinolaryngology Foundation, which has sponsored it throughout these years, within its statutory objectives of encouraging research and the dissemination of the specialty. A large number of people who believed in the initiative have worked long and heard since the initial days, when few articles were received, until today, when hundreds of papers are submitted annually to the journal.

\section{IAO Editors}

Ricardo Ferreira Bento (1997-1998).

Tanit Ganz Sanchez (1999-2005).

Marcelo Miguel Hueb (2006-2008).

Geraldo Pereira Jotz (2009-current) with Co-Editor Aline Bittencourt (2013-current).

In 2010, the Librarian Adilson Montefusco joined the journal team, bringing great professionalism and dynamism to its publication.

In 2013, Thieme Medical Publishers started editing the journal, and it then assumed an important position of international visibility. ${ }^{6}$

\section{Current Indexing Institutes}

2003-Lilacs and Lilacs-Express: Literatura Latino-Americana e do Caribe em Ciências da Saúde. ${ }^{7}$

\footnotetext{
(C) 2021. Fundação Otorrinolaringologia. All rights reserved.

This is an open access article published by

Thieme under the terms of the Creative

Commons Attribution-NonDerivative-

NonCommercial-License, permitting copying

and reproduction so long as the original work is

given appropriate credit. Contents may not be

used for commercial purposes, or adapted,

remixed, transformed or built upon. (https://

creativecommons.org/licenses/by-nc-nd/4.0/)

Thieme Revinter Publicações Ltda., Rua

do Matoso 170, Rio de Janeiro, RJ, CEP

20270-135, Brazil
}

DOI https://doi.org/ 10.1055/s-0041-1722895. ISSN 1809-9777. 
2004-Latindex: Sistema Regional de Información en Línea para Revistas Científicas de América Latina, el Caribe, España y Portugal. ${ }^{8}$

2006-DOAJ: Directory of Open Access Journals. ${ }^{9,10}$

2006-FUNPEC-RP: Fundação de Pesquisas Científicas de Ribeirão Preto. ${ }^{11}$

2010-SciELO: Scientific Electronic Library Online. ${ }^{4,12}$

2011-Scopus: Elsevier. ${ }^{13}$

2012-PubMed and PubMed Central (PMC). ${ }^{14}$

2013-Embase: Excerpta Medica Database - Elsevier. ${ }^{15}$

2019-Web of Science: Emerging Sources Citation Index (ESCI). ${ }^{16}$

\section{So far, IAO has published}

\begin{tabular}{|l|l|}
\hline Editions & Number \\
\hline Volumes & 25 \\
\hline Issues & 97 \\
\hline Supplements & 12 \\
\hline Documents & 5,920 \\
\hline
\end{tabular}

\section{History of publications (1997-2020)}

\begin{tabular}{|c|c|c|}
\hline $\begin{array}{l}\text { Document } \\
\text { type }\end{array}$ & Number & Definition \\
\hline $\begin{array}{l}\text { Original } \\
\text { article }\end{array}$ & 1,133 & $\begin{array}{l}\text { Original research or opinion. } \\
\text { However, case reports, technical } \\
\text { and research notes and short } \\
\text { communications are also } \\
\text { considered original articles. }\end{array}$ \\
\hline Review & 182 & $\begin{array}{l}\text { Significant review of original } \\
\text { researches. Educational items that } \\
\text { review specific issues within the } \\
\text { literature are also considered reviews. }\end{array}$ \\
\hline $\begin{array}{l}\text { Article in } \\
\text { press }\end{array}$ & 70 & $\begin{array}{l}\text { Article accepted and made } \\
\text { available online before the official } \\
\text { publication. }\end{array}$ \\
\hline Editorial & 87 & $\begin{array}{l}\text { Summary of several articles or } \\
\text { editorial opinions or news. }\end{array}$ \\
\hline Erratum & 1 & $\begin{array}{l}\text { Report of an error, correction or } \\
\text { retraction of a previously-published } \\
\text { paper. }\end{array}$ \\
\hline Letter & 9 & $\begin{array}{l}\text { Letter to or correspondence with } \\
\text { the editor. }\end{array}$ \\
\hline Note & 7 & Note, discussion, or commentary. \\
\hline $\begin{array}{l}\text { Conference } \\
\text { abstracts }\end{array}$ & 4,431 & $\begin{array}{l}\text { Proceedings can be serial or } \\
\text { non-serial publications, and they } \\
\text { may contain either the full articles } \\
\text { of the papers presented or only the } \\
\text { abstracts. }\end{array}$ \\
\hline
\end{tabular}

2019-continuous publication: to accelerate the publication of articles, the IAO journal adopted the continuous publication model, which enables the quick publication of articles. After approval and the writing of the editorial, the articles are automatically published online and indexed in the databases without the need to wait for the quarterly publication of the printed journal. ${ }^{17}$ 2020-video data innovation: new section of the journal in which high-level reviews will be published with videos of diagnoses and/or treatments. It is a great innovation, aligning scientific publication and technology. ${ }^{18}$

In the year of the COVID-19 pandemic, the journal was one of the first that published in its second edition of 2020 studies related to COVID-19, confirming its pioneering spirit since its foundation in $1997 .{ }^{19,20}$

\section{COVID-19: 19 publications}

\begin{tabular}{|l|l|}
\hline Document type & Number \\
\hline Editorial & 8 \\
\hline Original research & 2 \\
\hline Opinion article & 1 \\
\hline Letter to the editor & 3 \\
\hline Update article & 2 \\
\hline Systematic review & 3 \\
\hline
\end{tabular}

The editorial management adopted seeks excellence in editorial quality, integrity in the dissemination of knowledge, as well as the sustainability of the journal, and the internationalization and expansion of its visibility. Some of the strategies adopted are: the use of an electronic administrative system to process articles, the use of a similarity detection tool and guides to improve texts, in addition to the adoption of the rolling publication system.

This historic date must be celebrated, and I want to thank everyone who at some point contributed to the existence and continuity of the journal, as well as the authors who trusted it over the years.

To our editorial board and section editors, for the technical work of analyzing the submitted works and the peer review team. They are the scientific basis of this journal.

We cannot forget the entire team at the Otorhinolaryngology Foundation, especially our Director, Adriana Fozzati, and our President, Professor Richard Voegels, for their support and work.

Special thanks to the current editorial team: Professor Geraldo Jotz, "the tireless," our Chief Editor, and Aline Bittencourt, our extremely active Co-Editor. To our Librarian, Adilson Montefusco, for his thoroughness and efficiency, and to Thieme Medical Publishers for having believed in our work.

Let's move on! Let's learn from the past and look to the future! And IAO's future is guaranteed!

\section{References}

1 Miniti A, Bento RF. Editorial. Arq Fund Otorrinolaringol 1997;1 (01):1

2 Bento RF. International Archives of Otorhinolaryngology: 20 Years of Excellence!. Int Arch Otorhinolaryngol 2017;21(01):1-3. Doi: 10.1055/s-0036-1596039

3 Sanchez TG, Mion O, Bento RF, Miniti A. Editorial. Arq Otorrinolaringol 2005;9(03):172 
4 Jotz GP. A Indexação da Arquivos Internacionais de Otorrinolaringologia a SciELO. Um novo passo. Novos desafios!. Arq Otorrinolaringol 2009;13(04):361

5 Oliveira M. The internet's early days: the story of the internet's first moments in Brazil. Revista Pesquisa FAPESP [Internet] 2011 Feb [cited 2020 Dec 16];(180): [about 1 p.]. Available from: https://revistapesquisa.fapesp.br/en/the-internets-early-days/

6 Jotz GP, Bittencourt A. International archives of otorhinolaryngology and thieme medical publishers. Int Arch Otorhinolaryngol 2013;17(03):236. Doi: 10.7162/S1809-97772013000300001

7 Sanchez TG, Mion O, Bento RF, Miniti A. Editorial. Arq Otorrinolaringol 2003;7(01):4

8 Sanchez TG, Mion O, Bento RF, Miniti A. Editorial. Arq Otorrinolaringol 2004;8(04):256

9 Hueb MM. Editorial. Arq Int Otorrinolaringol 2008;12(04):480

10 DOAJ - Directory of Open Access Journals [Internet]. [cited 2016 Oct 20]. Available from: https://doaj.org/

11 FUNPEC-RP - Fundação de Pesquisas Científicas de Ribeirão Preto [Internet]. Sumários.org [cited 2016 Oct 20] Available from: http://www.sumarios.org/

12 SciELO [Internet]. International Archives of Otorhinolaryngology [cited 2016 Oct 19] Available from: http://www.scielo.br/iao

13 Elsevier. Scopus [Internet] [cited 2016 Oct 19]. Available from: https://www.scopus.com/
14 National Center for Biotechnology Information, U.S. National Library of Medicine. International Archives of Otorhinolaryngology: PubMed Central. [cited 2016 Oct 19]. Available from: https://www. ncbi.nlm.nih.gov/pmc/journals/2661/

15 Elsevier. Embase [cited 2016 Oct 21]. Available from: https:// www.embase.com

16 Jotz GP, Bittencourt AG, Montefusco AM. International Archives of Otorhinolaryngology is now Indexed in Emerging Sources Citation Index of Web of Science. Int Arch Otorhinolaryngol 2020;24(01): e1-e4. Doi: 10.1055/s-0039-3402452

17 Jotz GP, Bittencourt AG, Montefusco AM. International Archives of Otorhinolaryngology Continuous Publication: Speeding up the Publication of Articles. Int Arch Otorhinolaryngol 2019;23(03): e253. Doi: 10.1055/s-0039-1692698

18 Mello JF. The World Has Changed. Int Arch Otorhinolaryngol 2020; 24(03):e393. Doi: 10.1055/s-0040-1714144

19 Jotz GP, Voegels RL, Bento RF. Otorhinolaryngologists and Coronavirus Disease 2019 (COVID-19). Int Arch Otorhinolaryngol 2020;24(02):e125-e128. Doi: 10.1055/s-0040-1709724

20 Kulcsar MA, Montenegro FL, Arap SS, Tavares MR, Kowalski LP. High Risk of COVID-19 Infection for Head and Neck Surgeons. Int Arch Otorhinolaryngol 2020;24(02):e129-e130. Doi: 10.1055/s0040-1709725 